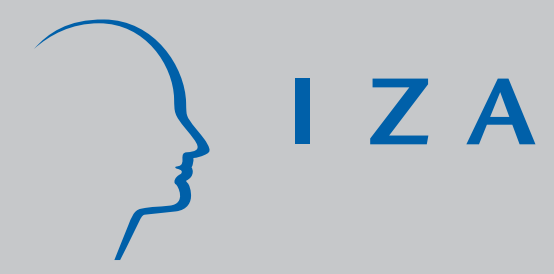

IZADP No. 1611

Multinationals and Plant Exit:

Evidence from Chile

Roberto Alvarez

Holger Görg

May 2005 


\title{
Multinationals and Plant Exit: Evidence from Chile
}

\author{
Roberto Alvarez \\ University of California, Los Angeles \\ Holger Görg \\ University of Nottingham, DIW Berlin \\ and IZA Bonn \\ Discussion Paper No. 1611 \\ May 2005
}

IZA
P.O. Box 7240
53072 Bonn
Germany

Phone: +49-228-3894-0

Fax: +49-228-3894-180

Email: iza@iza.org

Any opinions expressed here are those of the author(s) and not those of the institute. Research disseminated by IZA may include views on policy, but the institute itself takes no institutional policy positions.

The Institute for the Study of Labor (IZA) in Bonn is a local and virtual international research center and a place of communication between science, politics and business. IZA is an independent nonprofit company supported by Deutsche Post World Net. The center is associated with the University of Bonn and offers a stimulating research environment through its research networks, research support, and visitors and doctoral programs. IZA engages in (i) original and internationally competitive research in all fields of labor economics, (ii) development of policy concepts, and (iii) dissemination of research results and concepts to the interested public.

IZA Discussion Papers often represent preliminary work and are circulated to encourage discussion. Citation of such a paper should account for its provisional character. A revised version may be available directly from the author. 


\section{ABSTRACT \\ Multinationals and Plant Exit: Evidence from Chile*}

This paper examines the link between multinational enterprises and plant exit in Chile. We investigate three main questions: are affiliates of foreign multinationals more likely to exit than domestic firms? Does the exit probability of multinationals depend on its export orientation?, and Does the presence of multinationals affect the survival of other firms in the economy? Our results show that foreign plants are more likely to exit the economy, controlling for other firm and industry characteristics, only during the late 1990s, a period when the Chilean economy experience a massive slowdown. Our data also suggest that only domestic market oriented multinationals responded to this negative shock by being more "footloose"; this is not true for multinational exporters. We also find that the presence of multinationals has a positive effect on plant survival in the early 1990s. This positive effect, however, is fully captured by productivity, once controlling for TFP in our exit regressions we do not find any further impact of multinational presence on a plant's probability of exit.

JEL Classification: F2, L6

Keywords: exit, survival, multinationals, foreign direct investment, exporting

Corresponding author:

Holger Görg

School of Economics

Room B53, The Clive Granger Building

University of Nottingham

University Park

Nottingham NG7 2RD

United Kingdom

Email: holger.gorg@nottingham.ac.uk

\footnotetext{
* Holger Görg gratefully acknowledges financial support from the Leverhulme Trust (Grant No.
} F114/BF). 


\section{Introduction}

The potential impact of foreign direct investment (FDI) and multinationals (MNEs) on economic development of host countries has been prominent on the research agenda of trade and development economists in recent years. Much of the academic work has focussed on the question of detecting "productivity spillovers" from multinationals, i.e., whether or not domestic firms increase their productivity through learning and competition from MNEs. Recent examples include Aitken and Harrison (1999) and Javorcik (2004) who examine spillovers in Venezuela and Lithuania, respectively. Related work has examined the macroeconomic link between FDI and growth in cross-country growth regressions (Borensztein et al., 1998; Alfaro et al., 2004) as well as the potential wage effects of multinationals in the domestic economy (Aitken et al., 1996; Lipsey and Sjöholm, 2004).

What has been largely neglected in this literature is an analysis of the link between multinational enterprises and the survival of plants or firms in the host country. This is an important topic, however, not only because plant survival shapes the competitive landscape of the economy, but also because the persistence of jobs is linked to the survival of plants. Both of these issues can be expected to impact on welfare in the economy. We therefore attempt to investigate three questions in this paper. First, are affiliates of foreign multinationals more or less likely to exit than domestic firms? Second, is the exit probability of multinationals different according to their export orientation? Third, does the presence of multinationals affect the survival of other firms in the domestic economy?

As regards the first and second questions, there are a number of reasons why we may expect foreign affiliates to behave differently from domestic firms. One argument emphasises the notion of multinationals being more footloose, i.e., more likely to leave an economy than 
domestic firms if the economy experiences a negative shock (e.g, Flamm, 1984). ${ }^{1}$ This may be due to multinationals being part of an international production network in which production can be easily shifted between locations, and because they are likely to be less linked into the local economy through vertical or horizontal linkages. On the contrary, one may also argue that foreign affiliates are less likely to exit because investing abroad involves substantial sunk costs which are likely to be higher than for setting up a purely domestic plant in the host country. Hence, they may be reluctant to leave if the shock is only temporary.

As regards the role of exporting the expectation is again ambiguous. On the one hand, exporting multinationals are less reliant on the domestic product market and may therefore, in the presence of a negative shock in the domestic market, be better able to cushion the adverse impact and stay in the host country. On the other hand, exporters are even more likely to be involved in international production networks and therefore less likely to be linked into the domestic economy.

The empirical evidence on the impact of nationality on exit probabilities is rather limited and, to the best of our knowledge, has not included an analysis of the role of exporting by multinationals. Görg and Strobl (2003a) and Bernard and Sjöholm (2003) find that affiliates of foreign multinationals are more likely to exit than domestic firms when controlling for a number of plant and industry characteristics. These studies use plant level data for Ireland and Indonesia, respectively. ${ }^{2}$

Moving on to the third question - does the presence of multinationals in an industry affect plant survival? - one may again expect two opposite effects. On the one hand, the

\footnotetext{
${ }^{1}$ Flamm's theoretical argument is based on optimal portfolio theory. When there are negative changes in the economy, foreign investors readjust their optimal portfolio (which depends on country risk) and may therefore leave the economy.

${ }^{2}$ Bernard and Jensen (2004) undertake a related study investigating differences in survival for domestic plants and US multinationals in the US. They do not consider foreign multinationals in the US, however.
} 
entry and presence of multinationals increases competition in the host country and therefore may lead to the exit of domestic firms that are unable to cope with the increased competitive pressure. On the other hand, the presence of multinationals may generate spillovers, which allow domestic firms to learn and improve their productivity and efficiency. As the survival of firms is positively linked to efficiency (Audretsch, 1995) this would be expected to have positive effects on the survival of firms.

To our knowledge, there is only very limited evidence on this issue. Görg and Strobl (2003b) use Irish plant level data to examine the effect of the presence of multinationals on the survival of domestic plants. They find that there are positive effects on domestic high tech plants, but no effects on domestic plants operating in low tech industries. Their interpretation is that only plants in high tech industries have the necessary absorptive capacity to benefit from potential spillovers.

This paper provides a number of contributions to the literature. Firstly, we investigate in detail the three questions about the link between multinationals and plant exit simultaneously. Using plant level data for manufacturing industries in Chile we examine the determinants of exit probabilities of plants, paying particular attention to the role of the nationality of the plant as well as the presence of foreign multinationals in the industry. Analysing these issues at the same time is a novelty of our paper, as the small number of previous papers focused on either the role of nationality, or the impact of the presence of multinationals, in isolation. Secondly, in contrast to previous empirical evidence, in the data we are also able to distinguish exporting and non-exporting multinationals, and we investigate whether exporting activity by MNEs matters for their probability of exit.

Chile in particular is an interesting case as the economy experienced a major slowdown in the late 1990s which provides us with a natural experiment to identify directly 
the "footloose nature" of multinationals. If multinationals are indeed more "footloose" they may be expected to be more likely to leave the country especially during that period when it was hit by a negative shock. Previous literature did not analyze directly this issue but examined generally whether multinationals are more likely to exit than domestic firms.

We are the first to use data for a Latin American country, a region where inward FDI has increased substantially over the last twenty years or so. Chile has undergone phases of substantial trade and investment liberalisations imposing domestic plants to international competition, since the mid 1970s. ${ }^{3}$ Trade liberalization was accompanied by liberalisation of foreign direct investment. With the exception of controls for short-term capital inflows, suspended on April 2002, Chile’s investment regime is transparent and most sectors are open to foreigners without restriction ${ }^{4}$.

Our results show that there is robust evidence that foreign plants are more likely to exit only for the late 1990s, when the Chilean economy was in recession. This, thus, provides evidence that they are more footloose when the economy is hit by a negative shock. We also show that this is only true for foreign non-exporters as opposed to foreign exporters, suggesting that export-oriented multinationals are not as susceptible to adverse changes in the economy as domestic market oriented multinationals. The former may be substituting exports for domestic output and are hence able to fend off negative effects and are therefore able to sustain their operations in Chile. This may not be true for non-exporters, once the domestic

\footnotetext{
${ }^{3}$ A number of papers have looked at the effects of these phases of trade liberalisation on employment and plant productivity, see, for example, Pavcnik (2002) and Levinsohn (1999). However, to the best of our knowledge, the link between multinationals and plant exit has not been investigated thus far.

${ }^{4}$ Riveros et. al. (1995) describes the new regime for foreign investment under the Law Decree 600 established in 1975. The principles of this law may be summarized in three elements. First, these rules give national treatment to foreign investors. Second, the law guarantees free access to domestic markets. Finally, these rules also imply no government intervention in firm activities and destination of the invested resources.
} 
economy is hit by a negative shock they are more likely to stop operating than are multinational exporters or domestic plants.

As regards the effect of multinationals in an industry on plant survival we find some evidence of a survival enhancing effect of multinationals, particularly for the early 1990s. This effect, however, seems to be completely due to productivity improvements in plants following an influx of foreign multinationals.

The remainder of the paper is structured as follows. Section 2 describes the dataset used and presents some preliminary empirics. The empirical model is presented in Section 3 while Section 4 discusses the estimation results and robustness checks. Section 5 concludes.

\section{Data and Preliminary Empirics}

The empirical analysis is based on the Annual National Industrial Survey (ENIA) carried out by the National Institute of Statistics of Chile (INE). This plant level survey is representative of the universe of Chilean manufacturing plants with 10 or more workers. The dataset is available for the period 1979 to 2000, but exports and foreign ownership are only collected since 1990. Given that we are interested in studying the relationship between plant survival and multinationals, we use information for the period 1990 through 2000. A significant percentage of plants in the survey are actually single-plant firms. The INE updates the survey annually by incorporating plants that started operating during the year and excluding those plants that stopped operating for any reason.

Each plant has a unique identification number which allow us to identify entry and exit. For each plant and year, ENIA collects data on production, value added, sales, employment and wages (production and non-production), exports, investment, depreciation, energy usage, foreign licenses, and other plant characteristics. Plant ownership is identified by 
the percentage of capital owned by foreigners. We define a foreign plant as one with any foreign ownership. Most plants, however, have majority foreign ownership. ${ }^{5}$ In addition, plants are classified according to the International Standard Industrial Classification (ISIC) rev 2. Using 4-digit industry level price deflators, all financial variables were converted to constant 1985 pesos. Plants do not report information on capital stock, thus it was necessary to construct this variable using the perpetual inventory method for each plant.

Table 1 presents the distribution of plants according to ownership and export orientation. In 1990, foreign plants only represented 4.2 percent of total plants in the manufacturing industry. Their participation increased to 5.9 and 6.1 percent in 1995 and 2000, respectively. The majority of domestic plants are non-exporters, while a slightly larger share of multinationals are exporters. Also, in general the importance of exporters has increased in domestic and multinational plants between 1990 and 2000.

Although multinationals are relatively less important in terms of plant numbers they represent a large and growing share of employment, value-added, and exports as shown in Figure 1. Between 1990 and 2000, multinationals increased their importance in manufacturing employment from about 10 percent to more than 15 percent. Over the same period, their participation in exports and value-added rose almost three times. In 2000, foreign firms accounted for more than 30 per cent of manufacturing exports and value-added.

Another noteworthy point from Table 1 is that the total number of plants increased substantially between 1990 and 1995 but was back at its initial level in 2000. This suggests a substantial number of exits over the period. We investigate this further in Table 2 which shows that the exit rate increased from 21.4 percent in the $1990-1995$ period to almost 44

\footnotetext{
${ }^{5}$ In 1990 (1995), the median and mean of foreign capital participation is 99\% (100\%) and 74.5\% (82.3\%), respectively.
} 
percent during 1995 to 2000. This increase in exit rates is consistent with a slowdown of the Chilean economy after 1998. Between 1986 and 1997 the growth rate of the Chilean economy was about 7 percent per annum, one of the highest around the world. In 1998, however, the economy expanded at a lower rate of 3.2 percent, and 1999 experienced its first recession in two decades (-0.8 percent of GDP growth). This experience is arguably reflected in the increased exit rates in the latter 1990s.

One of the main issues of this paper is the question as to whether exit probabilities are different between domestic and foreign plants. In order to get a first impression of this, Table 3 divides the sample between foreign and domestic plants, and according to their export orientation. We are particularly interested in analyzing if there are statistically significant differences in the (unconditional) exit probability for different types of plants and time periods. Note firstly that, similar to the general sample, we find that for all types of plants exit rates increase in the period 1995-2000 compared to the early 1990s.

Panel A of Table 3 compares domestic and foreign-owned plants. The data show that between 1990 and 1995 foreign multinationals have a statistically significantly lower exit rate than domestic plants; a result that is in line with Görg and Strobl (2003a) and Bernard and Sjöholm (2003) who both find that in a simple comparison of unconditional exit rates, plants being part of a foreign multinational have lower rates than domestic plants. Our results also show that exit rates for both types of plants increased considerably in the $1995-2000$ interval, and that we now fail to find any statistically significant difference between the two. This suggests that the negative effects of the slowdown of the economy hit both types of plants in terms of increasing their average exit probabilities. All in all, these unconditional summary statistics indicate that, while exit rates increased in the period of a negative shock hitting the economy, multinationals do not appear to be more footloose than domestic plants. 
Recall that the data in Table 1 showed that the majority of domestic plants are nonexporters, while for multinationals the distribution between exporters and non-exporters is almost even. As exporters are generally more efficient than non-exporters (see Alvarez and Lopez, 2005, for Chilean evidence) we also distinguish exit rates for plants by export orientation. For domestic plants there is evidence that non-exporters are significantly more likely to exit than exporters (panel B). However, for multinationals, we do not find evidence of significant differences according to plant export orientation (panel C) and, hence, in the further preliminary empirics we treat foreign multinationals as a homogeneous group.

By contrasting multinationals with domestic exporters and non-exporters we find mixed results. Panel D shows that exit rate was significantly larger for foreign multinationals than for domestic exporters in the period 1995-2000 while there are no differences in the earlier period. By contrast, the data in panel $\mathrm{E}$ show similar exit rates for multinationals and domestic non-exporters in the latter period, but lower rates for multinationals between 1990 and 1995.

\section{Econometric Methodology}

The summary statistics in Table 3 suggested that the exit rate for multinationals was lower, at least in the early 1990s, than that for domestic plants. However, these are unconditional averages, which may merely reflect the effects of other plant or industry characteristics that are different for foreign and domestic plants. For example, large and more productive plants are generally expected to have higher survival (or, equivalently, lower exit) probabilities - and foreign multinationals are generally found to be larger and more productive than domestic plants (Lipsey, 2002). In fact, both Görg and Strobl (2003a) and Bernard and Sjöholm (2003) find that, once controlling for size and other covariates, foreign 
multinationals are more likely to exit than comparable domestic plants. In order to disentangle the effects of other covariates from the effect of ownership on plant exit, we therefore turn to an econometric modelling of the determinants of plant exit.

Our empirical approach is based on discrete model for the probability of exit, given by

$$
\operatorname{Pr}\left(\text { Exit }_{\mathrm{ij} \Delta t}\right)=\mathrm{f}\left(\alpha+\beta \mathrm{X}_{\mathrm{it}}+\gamma \mathrm{Z}_{\mathrm{jt}}+\mathrm{d}_{\mathrm{j}}+\mathrm{d}_{\Delta \mathrm{t}}+\varepsilon_{\mathrm{ij} \Delta \mathrm{t}}\right)
$$

where $\Delta \mathrm{t}$ is the time interval over which exit is defined. We estimate this model using a Probit. Exit is defined as the case of a plant observed at the beginning of the interval, but not observed at the end of this interval. $\mathrm{X}$ is vector of plant characteristics, $\mathrm{Z}$ is a vector of industry characteristics, and $\mathrm{d}_{\mathrm{j}}$ and $\mathrm{d}_{\Delta \mathrm{t}}$ are industry and period specific effects.

One potential advantage of our dataset is that we are able to identify plant exits for each year. Thus, our interval $\Delta \mathrm{t}$ may be a one-year period in principle. In such a case, we could follow some of the previous literature in estimating a Cox proportional hazard model. ${ }^{6}$ However, as evidenced by Benavente and Ferrada (2003) for this dataset, plant exit and entry may be due to reasons different than plant birth or death. ${ }^{7}$ Using year-to-year fluctuations increases the measurement error in our dependent variable. Moreover, year-to-year fluctuations in multinational shares may be negligible making difficult to identify some effect on plant survival. Third, plants shutdowns may take time to materialize given that agents do not immediately internalize changes in profitability in their decisions. Hence, we allow for an adjustment lag in plant exit.

Based on these considerations, we use a five-year period to define plant death. A plant death is defined as the case of a plant which exists in year $t$ but not in $t+5$. This implies that

\footnotetext{
${ }^{6}$ See, for example, Audretsch and Mahmood (1995), Mata and Portugal (1994), and Görg and Strobl (2003a,b).

${ }^{7}$ Benavente and Ferrada (2003) discuss how false entries and exits may be associated with plants that reach employment levels above or below the threshold of 10 workers. In addition, "deaths" may also be the result of plants that were not located at the time of the survey; did not have movement of capital; had their operations paralyzed; were under investigation by the Internal Tax Service (SII); or had merged with another plant.
} 
we have at most two observations per plant: one covering 1990 - 1995, and one for 1995 2000. To check the robustness of our results to the definition of this variable and time period, we also re-estimated the model for plant exit measured over a 3-year period. In both cases, all explanatory variables are measured at the beginning of the period.

$\mathrm{X}$ includes a number of covariates which have commonly been found to be important for explaining plant exit. In terms of plant characteristics the model includes size, age, productivity, as well as dummy variables to indicate whether a plant is an exporter, and whether it is foreign-owned. Size and age have been found in a number of studies to be important determinants of plant survival; in general, older and larger plants have lower probabilities of exiting (e.g., Dunne et al., 1989; Salvanes and Tveteras, 2004), which is consistent with theoretical models of industry dynamics that emphasize firm learning, as in Jovanovic (1982).

As plant survival can be expected to be positively related to plant efficiency, we include a measure of (log) total factor productivity in the estimation. TFP is calculated as the residual from a Cobb-Douglas production function, which is estimated separately for each 3digit industry using plant level data. In order to deal with the potential simultaneity problem in estimating plant level production functions we employ the method proposed by Levinsohn and Petrin (2003). ${ }^{8}$ Furthermore, as the recent literature has highlighted the fact that exporters are generally more productive than non-exporters (e.g., Clerides et al., 1998; Alvarez and Lopez, 2005) we also control for the export status of the plant using a dummy equal to one if the plant exports, zero if not.

\footnotetext{
${ }^{8}$ Levinsohn and Petrin (2003) suggest to overcome the simultaneity problem in production function estimations using inputs as instruments. We implement their approach, using plant level energy consumption as instrument.
} 
We also include a number of industry characteristics (calculated at the 3-digit level) that are expected to impact on plant survival. A measure of industry minimum efficient scale, and the Herfindahl index are used in the model in order to control for different survival probabilities depending on the level of competition in the industry. ${ }^{9}$ The expectation is not clear-cut, however. On the one hand, highly concentrated industries sustain high price cost margins, which should reduce the exit probabilities (Audretsch, 1995). On the other hand, however, the competitive pressure in highly concentrated industries may increase the probability of exit. To allow also for the possibility that plant exit is lower in fast growing industries (Audretsch, 1995) we include the net sectoral employment growth rate as additional covariate.

The main variables of interest to us are those that are expected to capture the relationship between multinationals and plant exit. Firstly, we include a dummy variable which is equal to one if a plant is foreign-owned. This variable thus indicates whether or not exit probabilities of plants are different depending on whether they are foreign or domestic owned. In case foreign multinationals are more footloose than domestic plants we expect a positive relationship between this dummy and the probability of exit, in particular in the late 1990s when the economy was undergoing a negative shock.

Secondly, we include a measure of multinational presence in the 3-digit industry (multinational share) in the estimation. This variable captures the effect of multinationals in the industry on the exit rates of plants. As argued in the introduction, the expected effect is positive if there are positive spillovers from multinationals to other plants in the industry, or negative if an adverse competition effect outweighs any potential spillover benefits.

\footnotetext{
${ }^{9}$ Minimum efficient scale is calculated as the median plant size (in terms of employment) in the industry. See Sutton (1991) for a discussion of why this may be considered an empirically appropriate measure of MES. The Herfindahl index is defined in terms of plants' sales shares.
} 
Following the literature on productivity spillovers we calculate the variable as employment in multinationals divided by total employment in the industry, to give an indication of the importance of multinationals in the sector.

\section{Empirical Results}

Table 4 presents the results of the baseline estimations of the probit model. Note that the regressions also include a dummy variable for the period 1995 - 2000 to allow for the considerable increase in the average exit ratio in that period compared to the early 1990s. From column (1), which excludes the multinational share variable, we find that total factor productivity, age and size have the predicted signs - they all reduce the exit probability - and are highly statistically significant. Also, industry growth is associated with lower exit probabilities (again as expected), while the 95-00 dummy is positive, reflecting the findings in the summary statistics. Note that none of the other plant or industry characteristics including the foreign ownership dummy - exert any statistically significant impact on plant survival in our regressions.

Column (2) adds the multinational share in industry employment into the regression. This variable also turns out to be statistically insignificant and the inclusion of it does not change any of the other coefficients in the previous estimation. These results imply that, on average, there is no relationship between foreign ownership and plant exit over the analysed period. Controlling for other plant and industry characteristics we do not find evidence that foreign plants are more footloose than domestic plants, and we also fail to detect any impact of the presence of multinationals on the probability of exit in the same 3-digit industry.

When discussing the "footloose" nature of multinationals one generally has in mind that they are more likely to respond to negative shocks to the economy than domestic plants, 
and that this response is greater volatility in investment (Flamm, 1984). In our case, we would therefore expect that foreign owned plants are more likely to exit if there are adverse changes in the economy. Above we discussed the decline in the Chilean economy in the late 1990s, and we would therefore conjecture that the footloose nature of multinationals should be reflected in them being more likely to exit in the latter period of the 1990s in particular. The summary statistics presented in Table 3 suggested that exit rates of foreign-owned plants increased considerably in the 1995 to 2000 period, which would be in line with this argument. To investigate this issue in more detail we interact the foreign ownership dummy with the dummy for the 1995 - 2000 period. The result of this estimation is reported in column 3 . We indeed find that the probability of exiting in the 1995-2000 period is statistically significantly higher for foreign-owned plants. This evidence is consistent with the argument that multinationals are more likely to readjust their investment decisions and exit if the economy is hit by a negative shock. ${ }^{10}$

Column (4) provides a robustness check for the previous estimation. Rather than defining the interaction term only for the foreign-ownership dummy we interacted all variables. The Chi2 statistic allows us to reject the hypothesis that all interaction terms are jointly equal to zero, allowing us to prefer this estimation to the ones presented previously. However, apart from the foreign ownership interaction, which is similar to the coefficient in column (3), the only statistically significant interaction term is for size, indicating that the effect of size on exit is less in the late than in the early 1990s. In particular, the interaction term with the multinational share variable is also statistically insignificant, again not

\footnotetext{
${ }^{10}$ To check whether this result is robust to different estimation techniques we present in Appendix I estimations of the equation in column (3) using random effects probit and logit and fixed effects logit. The results are similar to the ones reported in Table 4 and indicate that they are robust to controlling for plant level heterogeneity.
} 
providing any evidence for a link between the presence of multinationals and exit rates of Chilean manufacturing plants.

The joint statistical significance of all interaction terms suggests that splitting the sample into two, for 1990-1995 and 1995-2000, is more appropriate than pooling. Columns (1) and (2) in Table 5 present the results of these estimations. Again we find a statistically significant and positive coefficient on the foreign-owned dummy only for the latter period, substantiating the previous results. We, however, still fail to detect a link between multinational presence in the industry and plant exit rates.

How robust are these results to the definition of exit over a five year period? In columns (3) to (5) in Table 5 we define the plant exit rate over three rather than five years as in the previous regressions. The probit model is estimated for the three time periods separately. We find a similar positive coefficient on the foreign ownership dummy only for the period from 1996 onwards, although this coefficient in this regression is only statistically significant at the 11 percent level. The other variables are also similar in sign, magnitude and statistical significance to the earlier results based on five year rates, suggesting that they are robust to the definition of exit rates.

Our results thus far imply that the presence of multinationals in an industry does not have any relationship on plants’ probabilities of exiting when controlling for other plant and industry characteristics. As pointed out above, one may expect a negative effect if multinationals crowd out other competitors, or a positive relationship if there are spillovers. In the case of the latter, we would expect firms to improve their TFP following an increase in the presence of multinationals. Such an effect would, hence, be absorbed by the TFP variable in our regression. In order to check whether this may influence our results we re-estimate equation (1) without controlling for TFP. These results are shown in Table 6. While the 
coefficients on other covariates remain essentially unchanged, we now find a statistically significantly negative coefficient on multinational share for the 1990 - 1995 period only (see columns 1 and 2). We do not observe such effects for the period of economic slowdown in the late 1990s, however. Notice from columns (3) to (5) that this result is also obtained when using the three year definition of exit rates. ${ }^{11}$

All regressions thus far included a dummy variable to identify exporters, however, this variable has consistently turned out to be statistically insignificant. This dummy variable, of course, is defined over domestic and foreign-owned plants, treating these two groups of plants as homogeneous. This may be a strong assumption and in order to relax this we define four different types of plants: domestic non-exporters, domestic exporters, multinational nonexporters and multinational exporters. The probit regressions including these four types of plants (with domestic non-exporters as the base group) are reported in Table 7. Columns (3) and (4) show that we only find that multinational non-exporters are more footloose than domestic non-exporters; the same is not true for multinational exporters. We find the same results in column (9) and (10), although the coefficient is only statistically significant at the 10 percent level.

This suggests that export-oriented multinationals are not as susceptible to adverse changes in the economy as domestic market oriented multinationals. The former may be substituting exports for domestic output and are hence able to fend off negative effects and are therefore able to sustain their operations in Chile. This may not be true for non-exporters,

\footnotetext{
${ }^{11}$ In order to check our conjecture we also regressed TFP on multinational share in estimations controlling for plant level heterogeneity. These estimations, which are not reported here to save space, show that there is no statistically significant positive impact of multinationals share on plant level TFP. This suggests that the TFP variable included in our exit regressions also picks up some element of plant level heterogeneity that is related with exit.
} 
once the domestic economy is hit by a negative shock they are more likely to stop operating than are multinational exporters or domestic plants.

\section{Conclusion}

This paper examines the link between multinational enterprises and plant exit in Chilean manufacturing industries. We investigate three related questions: are affiliates of foreign multinationals more or less likely to exit than domestic firms? Does the exit probability of multinationals depend on its export orientation? Does the presence of multinationals affect the survival of other firms in the domestic economy? The first question has been debated in the literature since plants of foreign multinationals may be quicker to leave the economy in the presence of negative shocks. Chile is arguably a good case study to analyse this issue as it provides us with a natural experiment, given the recession in the economy in the late 1990s.

Our results show that foreign plants are indeed more likely to exit the economy, controlling for other firm and industry characteristics, than domestic plants. However, this result only holds for the late 1990s, the period when the Chilean economy experienced a massive slowdown. Our data also suggest that only domestic market oriented multinationals responded to this negative shock by being more likely to exit than domestic plants, this is not true for multinational exporters. This suggests that the latter type of plant is better able to absorb the negative shock and remain in the host country - a finding that we aim to investigate further in future research.

The second research question examines whether or not there are "spillovers" from multinationals on plants. We find that the presence of multinationals has indeed a positive effect on plant survival in the early 1990s. This positive effect, however, is fully captured by 
productivity improvements, once controlling for TFP in our exit regressions we do not find any further impact of multinational presence on a plant's probability of exit. 


\section{References}

Aitken, Brian J. and Ann E. Harrison (1999), Do domestic firms benefit from direct foreign investment? Evidence from Venezuela, American Economic Review 89, 605-618.

Aitken, Brian J., Ann E. Harrison and Robert E. Lipsey (1996), Wages and foreign ownership: A comparative study of Mexico, Venezuela, and the United States, Journal of International Economics 40, 345-371.

Alfaro, Laura, Areendam Chanda, Sebnem Kalemli-Ozcan and Selin Sayek (2004), “FDI and economic growth: The role of local financial markets, Journal of International Economics, 64, 89-112.

Alvarez, Roberto and Ricardo A. Lopez (2005), "Exporting and performance: Evidence from Chilean plants”, Canadian Journal of Economics, forthcoming.

Audretsch, David B. (1995), Innovation and Industry Evolution, MIT Press, Cambridge M.A.

Audretsch, David B. and Talat Mahmood (1995), New-firm survival: new results using a hazard function, Review of Economics and Statistics, 77, 99-103.

Benavente, Jose Miguel and Christian Ferrada (2003), Probability of survival of new manufacturing plants: the case of Chile.” Mimeo, University of Chile.

Bernard, Andrew B. and J. Bradford Jensen (2004), Firm structure, multinationals, and manufacturing plant deaths, mimeo.

Bernard, Andrew B. and Fredrik Sjöholm (2003), Foreign owners and plant survival, NBER Working Paper 10039. 
Borensztein, Eduardo R., Jose De Gregorio and John-Wha Lee (1998), How does foreign direct investment affect economic growth?, Journal of International Economics, 45, 115-135.

Clerides, Sofronis K., Saul Lach, and James R. Tybout (1998), Is learning by exporting important? Micro-dynamic evidence from Columbia, Mexico and Morocco, Quarterly Journal of Economics, 113, 903-948.

Flamm, Kenneth (1984), The volatility of offshore investment, Journal of Development Economics, 16, 231-248.

Görg, Holger and Eric Strobl (2003a), Footloose multinationals? The Manchester School, $71,1-19$.

Görg, Holger and Eric Strobl (2003b), Multinational companies, technology spillovers and plant survival, Scandinavian Journal of Economics, 105, 581-595.

Javorcik, Beata S. (2004), Does foreign direct investment increase the productivity of domestic firms? In search of spillovers through backward linkages, American Economic Review, 94, 605-627.

Jovanovic, Boyan (1982), Selection and evolution of industry, Econometrica, 50, 649-670.

Levinsohn, James (1999), Employment responses to international liberalization in Chile, Journal of International Economics, 47, 321-344.

Levinsohn, James and Amil Petrin (2003), Estimating production functions using inputs to control for observables, Review of Economic Studies, 70, 317-341.

Lipsey, Robert E. (2002), Home and host country effects of FDI, NBER Working Paper 9293. 
Lipsey, Robert E. and Fredrik Sjöholm (2004), Foreign direct investment and wages in Indonesian manufacturing, Journal of Development Economics, 73, 415-422.

Mata, Jose and Pedro Portugal (1994), Life duration of new firms, Journal of Industrial Economics, 42, 227-245.

Pavcnik, Nina (2002), Trade liberalization, exit, and productivity improvements: Evidence from Chilean plants, Review of Economic Studies, 69, 245-276.

Riveros, Luis, Vatter, J. and Manuel Agosin (1995), Foreign direct investment in Chile, 1987-1993: utilization of comparative advantage and debt conversion, in Manuel Agosin (ed.): Foreign Direct Investment in Latin America. Johns Hopkins University Press.

Salvanes and Tveteras (2004), Plant exit, vintage capital, and the business cycle, Journal of Industrial Economics, 52(2), 255-276.

Sutton, John (1991), Sunk Costs and Market Structure, MIT Press, Cambridge M.A. 
Table 1: Plant Distributions by Nationality Types

\begin{tabular}{l|cccccc}
\hline & \multicolumn{2}{|c}{1990} & \multicolumn{2}{c}{1995} & \multicolumn{2}{c}{2000} \\
\hline & Plants & $\%$ & Plants & $\%$ & Plants & $\%$ \\
Domestic & 4,395 & 95.9 & 4,812 & 94.1 & 4,262 & 94.0 \\
Non-exporter & 3,744 & 81.7 & 3,839 & 75.1 & 3,524 & 77.7 \\
Exporter & 651 & 14.2 & 973 & 19.0 & 738 & 16.3 \\
Multinational & 190 & 4.2 & 300 & 5.9 & 273 & 6.1 \\
$\quad$ Non-exporter & 81 & 1.8 & 139 & 2.7 & 111 & 2.5 \\
$\quad$ Exporter & 109 & 2.4 & 161 & 3.2 & 162 & 3.6 \\
Total & 4,585 & 100.0 & 5,112 & 100.0 & 4,535 & 100.0 \\
\hline
\end{tabular}

Table 2: Exit Rates

\begin{tabular}{l|cccc}
\hline & \multicolumn{2}{|c}{$1990-1995$} & \multicolumn{2}{c}{$1995-2000$} \\
\hline \multirow{3}{*}{ No Exit } & \# Plants & Percentage & \# Plants & Percentage \\
Exit & 3,604 & 78.6 & 2,872 & 56.2 \\
Total & 981 & 21.4 & 2,240 & 43.8 \\
\hline
\end{tabular}

Source: Authors' own calculations based on ENIA. 
Table 3: Mean Tests for Probability of Exit

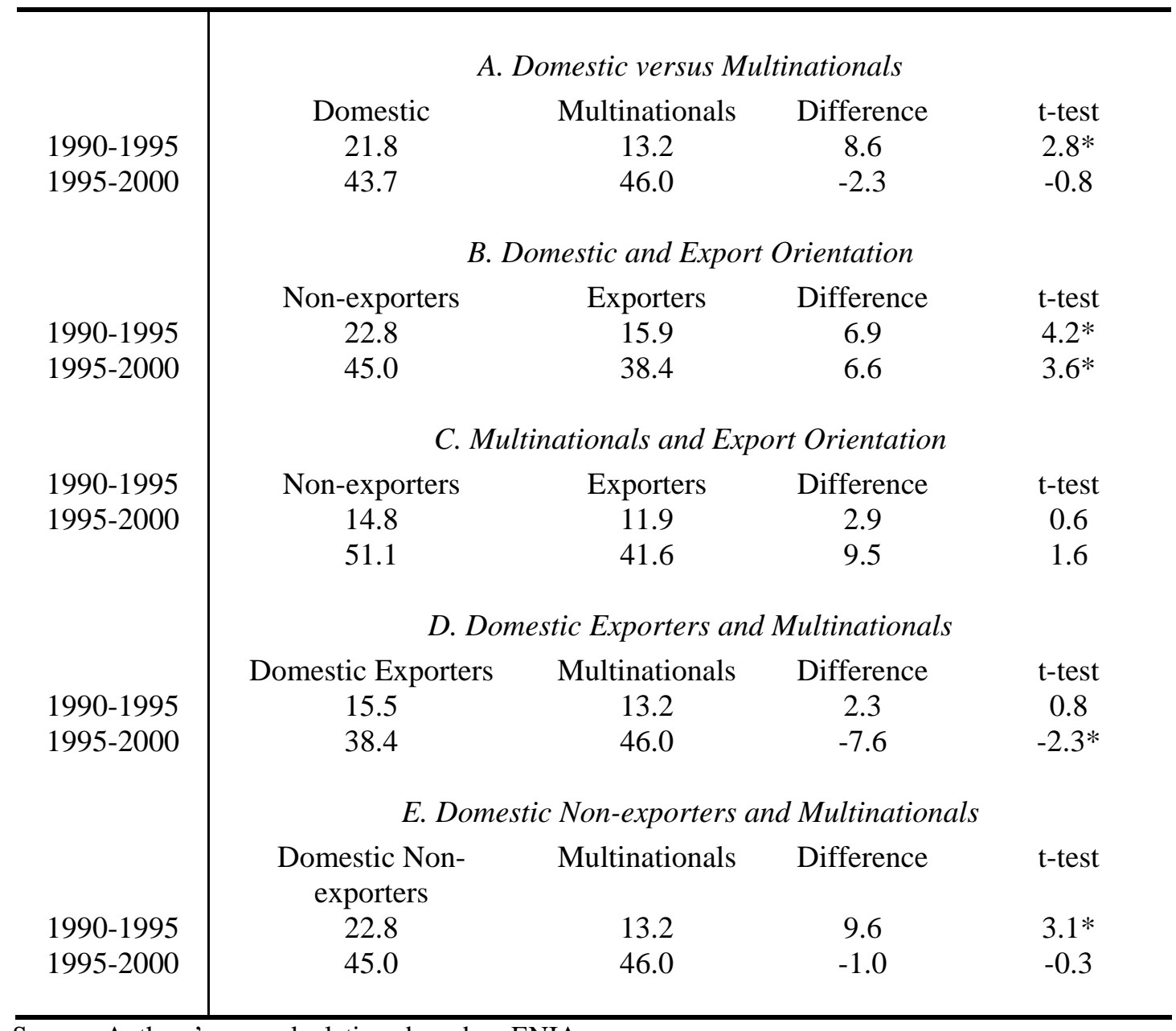

Source: Authors’ own calculations based on ENIA. 
Table 4: Probit Results with Interactive Terms

(Marginal changes)

\begin{tabular}{|c|c|c|c|c|}
\hline & $(1)$ & $(2)$ & (3) & (4) \\
\hline Multinational & $\begin{array}{l}0.042 \\
(1.68)\end{array}$ & $\begin{array}{l}0.042 \\
(1.68)\end{array}$ & $\begin{array}{l}-0.038 \\
(1.06)\end{array}$ & $\begin{array}{l}-0.031 \\
(0.84)\end{array}$ \\
\hline TFP & $\begin{array}{c}-0.043 \\
(6.11)^{* *}\end{array}$ & $\begin{array}{c}-0.043 \\
(6.06)^{* *}\end{array}$ & $\begin{array}{c}-0.042 \\
(5.88)^{* *}\end{array}$ & $\begin{array}{c}-0.043 \\
(7.17)^{* *}\end{array}$ \\
\hline Age & $\begin{array}{c}-0.059 \\
(6.30)^{* *}\end{array}$ & $\begin{array}{c}-0.059 \\
(6.30)^{* *}\end{array}$ & $\begin{array}{c}-0.059 \\
(6.37)^{* *}\end{array}$ & $\begin{array}{c}-0.080 \\
(6.08)^{* *}\end{array}$ \\
\hline Size & $\begin{array}{c}-0.055 \\
(7.31)^{* *}\end{array}$ & $\begin{array}{c}-0.055 \\
(7.31)^{* *}\end{array}$ & $\begin{array}{c}-0.055 \\
(7.26)^{* *}\end{array}$ & $\begin{array}{c}-0.073 \\
(6.26)^{* *}\end{array}$ \\
\hline Exporter & $\begin{array}{l}0.008 \\
(0.24)\end{array}$ & $\begin{array}{l}0.008 \\
(0.24)\end{array}$ & $\begin{array}{l}-0.012 \\
(0.23)\end{array}$ & $\begin{array}{l}0.008 \\
(0.16)\end{array}$ \\
\hline MES & $\begin{array}{c}0.000 \\
(0.00)\end{array}$ & $\begin{array}{r}-0.000 \\
(0.00)\end{array}$ & $\begin{array}{l}0.001 \\
(0.02)\end{array}$ & $\begin{array}{c}-0.038 \\
(0.43)\end{array}$ \\
\hline Herfindahl & $\begin{array}{l}-0.800 \\
(1.50)\end{array}$ & $\begin{array}{l}-0.802 \\
(1.54)\end{array}$ & $\begin{array}{l}-0.721 \\
(1.42)\end{array}$ & $\begin{array}{l}-0.897 \\
(1.48)\end{array}$ \\
\hline Multinational share & -- & $\begin{array}{l}-0.020 \\
(0.07)\end{array}$ & $\begin{array}{l}-0.037 \\
(0.13)\end{array}$ & $\begin{array}{l}-0.000 \\
(0.00)\end{array}$ \\
\hline Growth & $\begin{array}{c}-0.151 \\
(2.16)^{*}\end{array}$ & $\begin{array}{l}-0.150 \\
(2.11)^{*}\end{array}$ & $\begin{array}{l}-0.158 \\
(2.11)^{*}\end{array}$ & $\begin{array}{l}-0.253 \\
(2.53)^{*}\end{array}$ \\
\hline 1995-2000 (D95-00) & $\begin{array}{c}0.196 \\
(7.74)^{* *}\end{array}$ & $\begin{array}{c}0.196 \\
(7.54)^{* *}\end{array}$ & $\begin{array}{c}0.183 \\
(5.90)^{* *}\end{array}$ & $\begin{array}{l}0.158 \\
(0.79)\end{array}$ \\
\hline Multinational*D95-00 & $\begin{array}{l}-- \\
--\end{array}$ & $\begin{array}{l}-- \\
--\end{array}$ & $\begin{array}{c}0.121 \\
(2.93)^{* *}\end{array}$ & $\begin{array}{c}0.109 \\
(2.50)^{*}\end{array}$ \\
\hline Exporter*D95-00 & $\begin{array}{l}-- \\
--\end{array}$ & $\begin{array}{l}-- \\
--\end{array}$ & $\begin{array}{l}0.031 \\
(0.78)\end{array}$ & $\begin{array}{l}-0.003 \\
(0.09)\end{array}$ \\
\hline TFP*D95-00 & $\begin{array}{l}-- \\
--\end{array}$ & $\begin{array}{l}-- \\
--\end{array}$ & $\begin{array}{l}-- \\
--\end{array}$ & $\begin{array}{l}0.003 \\
(0.35)\end{array}$ \\
\hline Age*D95-00 & $\begin{array}{l}-- \\
--\end{array}$ & $\begin{array}{l}-- \\
--\end{array}$ & $\begin{array}{l}-- \\
--\end{array}$ & $\begin{array}{l}0.029 \\
(1.78)\end{array}$ \\
\hline Size*D95-00 & $\begin{array}{l}-- \\
--\end{array}$ & $\begin{array}{l}-- \\
--\end{array}$ & $\begin{array}{l}-- \\
--\end{array}$ & $\begin{array}{c}0.029 \\
(2.31)^{*}\end{array}$ \\
\hline MES*D95-00 & $\begin{array}{l}-- \\
--\end{array}$ & $\begin{array}{l}-- \\
--\end{array}$ & $\begin{array}{l}-- \\
--\end{array}$ & $\begin{array}{l}-0.041 \\
(0.71)\end{array}$ \\
\hline Herfindahl*D95-00 & $\begin{array}{l}-- \\
--\end{array}$ & $\begin{array}{l}-- \\
--\end{array}$ & $\begin{array}{l}-- \\
--\end{array}$ & $\begin{array}{l}0.169 \\
(0.59)\end{array}$ \\
\hline Growth*D95-00 & $\begin{array}{l}-- \\
--\end{array}$ & $\begin{array}{l}-- \\
--\end{array}$ & $\begin{array}{l}-- \\
--\end{array}$ & $\begin{array}{l}0.165 \\
(1.34)\end{array}$ \\
\hline Mult. Share*D95-00 & $\begin{array}{l}-- \\
--\end{array}$ & $\begin{array}{l}-- \\
--\end{array}$ & $\begin{array}{l}-- \\
--\end{array}$ & $\begin{array}{l}0.014 \\
(0.06)\end{array}$ \\
\hline Observations & 8603 & 8603 & 8603 & 8603 \\
\hline
\end{tabular}

Robust $\mathrm{z}$ statistics in parentheses, * significant at 5\%; ** significant at $1 \%$. Standard errors are clustered at three-digit industry level. Test results for $\mathrm{H}_{0}$ : all interactive terms are zero. (3): chi2(2) = 13.61, Prob > chi2 $=0.0011$, and (4): chi2(9) $=42.32$, Prob $>$ chi2 $=0.0000$ 
Table 5: Probit Results: 5-and-3-year period

(Marginal changes)

\begin{tabular}{l|cc|ccc}
\hline & $\begin{array}{c}1990-1995 \\
(1)\end{array}$ & $\begin{array}{c}1995-2000 \\
(2)\end{array}$ & $\begin{array}{c}1990-1993 \\
(3)\end{array}$ & $\begin{array}{c}1993-1996 \\
(4)\end{array}$ & $\begin{array}{c}1996-1999 \\
(5)\end{array}$ \\
\hline \multirow{4}{*}{ Multinational } & & & & & \\
& -0.034 & 0.069 & -0.015 & -0.010 & 0.069 \\
TFP & $(1.19)$ & $(2.13)^{*}$ & $(0.59)$ & $(0.48)$ & $(1.63)$ \\
Age & -0.011 & -0.011 & -0.011 & -0.007 & -0.018 \\
& $(2.69)^{* *}$ & $(1.25)$ & $(2.35)^{*}$ & $(1.97)^{*}$ & $(3.23)^{* *}$ \\
Size & -0.068 & -0.054 & -0.048 & -0.041 & -0.045 \\
& $(7.56)^{* *}$ & $(4.55)^{* *}$ & $(6.47)^{* *}$ & $(5.36)^{* *}$ & $(5.34)^{* *}$ \\
Exporter & -0.060 & -0.047 & -0.037 & -0.072 & -0.048 \\
& $(8.26)^{* *}$ & $(5.05)^{* *}$ & $(7.41)^{* *}$ & $(6.47)^{* *}$ & $(5.04)^{* *}$ \\
MES & 0.007 & 0.000 & 0.016 & 0.018 & -0.005 \\
Herfindahl & $(0.20)$ & $(0.01)$ & $(0.61)$ & $(0.75)$ & $(0.16)$ \\
\multirow{4}{*}{ Growth } & -0.002 & 0.012 & -0.006 & 0.010 & 0.046 \\
& $(0.06)$ & $(0.28)$ & $(0.22)$ & $(0.26)$ & $(1.20)$ \\
Multinational share & -0.069 & -0.121 & -0.046 & -0.212 & -0.051 \\
& $(0.37)$ & $(0.74)$ & $(0.40)$ & $(1.33)$ & $(0.32)$ \\
& -0.201 & -0.139 & -0.072 & -0.174 & -0.130 \\
Observations & $(4.43)^{* *}$ & $(0.98)$ & $(1.77)$ & $(2.45)^{*}$ & $(0.97)$ \\
& -0.117 & -0.075 & -0.147 & -0.102 & -0.171 \\
& $(1.01)$ & $(0.26)$ & $(1.07)$ & $(0.72)$ & $(1.25)$ \\
& & & & & \\
& 4060 & 4543 & 4060 & 4460 & 4434 \\
\hline
\end{tabular}

Robust z statistics in parentheses, * significant at 5\%; ** significant at 1\%. Standard errors are clustered at threedigit industry level. 
Table 6: Probit Results without TFP, 5-and-3-year periods

(Marginal changes)

\begin{tabular}{l|cc|ccc}
\hline & $\begin{array}{c}1990-1995 \\
(1)\end{array}$ & $\begin{array}{c}1995-2000 \\
(2)\end{array}$ & $\begin{array}{c}1990-1993 \\
(3)\end{array}$ & $\begin{array}{c}1993-1996 \\
(4)\end{array}$ & $\begin{array}{c}1996-1999 \\
(5)\end{array}$ \\
\hline \multirow{3}{*}{ Multinational } & & & & & \\
& -0.034 & 0.069 & -0.015 & -0.010 & 0.072 \\
Age & $(1.17)$ & $(2.12)^{*}$ & $(0.60)$ & $(0.52)$ & $(1.66)$ \\
& -0.069 & -0.054 & -0.050 & -0.042 & -0.046 \\
Size & $(8.02)^{* *}$ & $(4.53)^{* *}$ & $(7.16)^{* *}$ & $(5.42)^{* *}$ & $(5.29)^{* *}$ \\
Exporter & -0.061 & -0.048 & -0.039 & -0.072 & -0.050 \\
MES & $(9.28)^{* *}$ & $(5.08)^{* *}$ & $(7.08)^{* *}$ & $(6.71)^{* *}$ & $(5.64)^{* *}$ \\
& 0.002 & -0.002 & 0.011 & 0.016 & -0.008 \\
Herfindahl & $(0.06)$ & $(0.06)$ & $(0.42)$ & $(0.66)$ & $(0.24)$ \\
Growth & 0.015 & 0.013 & 0.012 & 0.018 & 0.042 \\
Multinational & $(0.83)$ & $(0.36)$ & $(0.79)$ & $(0.65)$ & $(1.47)$ \\
share & -0.052 & -0.110 & -0.035 & -0.220 & 0.062 \\
& $(0.33)$ & $(0.76)$ & $(0.45)$ & $(1.50)$ & $(0.39)$ \\
Observations & -0.202 & -0.236 & -0.047 & -0.213 & -0.269 \\
\hline
\end{tabular}

Robust z statistics in parentheses, * significant at 5\%; ** significant at $1 \%$. Standard errors are clustered at threedigit industry level. 
Table 7: Probit Results with Export Status, 5-and-3-year periods

(Marginal changes)

\begin{tabular}{|c|c|c|c|c|c|c|c|c|c|c|}
\hline & \multicolumn{2}{|c|}{$1990-1995$} & \multicolumn{2}{|c|}{$1995-2000$} & \multicolumn{2}{|c|}{ 1990-1993 } & \multicolumn{2}{|c|}{ 1993-1996 } & \multicolumn{2}{|c|}{ 1996-1999 } \\
\hline & $(1)$ & $(2)$ & (3) & $(4)$ & (5) & $(6)$ & $(7)$ & $(8)$ & $(9)$ & $(10)$ \\
\hline \multirow[t]{2}{*}{ Dom. \& exporter } & 0.009 & 0.005 & 0.005 & 0.002 & 0.019 & 0.014 & 0.023 & 0.021 & -0.003 & -0.005 \\
\hline & $(0.27)$ & $(0.14)$ & $(0.14)$ & $(0.07)$ & $(0.72)$ & $(0.55)$ & $(0.95)$ & $(0.85)$ & $(0.09)$ & $(0.14)$ \\
\hline \multirow[t]{2}{*}{ MNC \& non-exporter } & -0.020 & -0.017 & 0.095 & 0.093 & 0.002 & 0.004 & 0.030 & 0.028 & 0.090 & 0.100 \\
\hline & $(0.52)$ & $(0.46)$ & $(2.21)^{*}$ & $(2.14)^{*}$ & $(0.06)$ & $(0.10)$ & $(0.87)$ & $(0.80)$ & (1.61) & (1.79) \\
\hline MNC \& exporter & -0.038 & -0.043 & 0.050 & 0.048 & -0.013 & -0.019 & -0.018 & -0.021 & 0.056 & 0.053 \\
\hline \multirow[t]{2}{*}{ TFP } & -0.011 & -- & -0.011 & -- & -0.011 & -- & -0.007 & -- & -0.018 & -- \\
\hline & $(2.69) * *$ & -- & $(1.26)$ & -- & $(2.35)^{*}$ & -- & $(1.98)^{*}$ & -- & $(3.20)^{* *}$ & -- \\
\hline \multirow[t]{2}{*}{ Age } & -0.068 & -0.069 & -0.054 & -0.054 & -0.048 & -0.050 & -0.041 & -0.042 & -0.045 & -0.046 \\
\hline & $(7.56)^{* *}$ & $(8.01)^{* *}$ & $(4.52)^{* *}$ & $(4.50) * *$ & $(6.48)^{* *}$ & $(7.17)^{* *}$ & $(5.29) * *$ & $(5.36)^{* *}$ & $(5.31)^{* *}$ & $(5.26)^{* *}$ \\
\hline \multirow[t]{2}{*}{ Size } & -0.060 & -0.061 & -0.047 & -0.048 & -0.037 & -0.039 & -0.072 & -0.072 & -0.048 & -0.050 \\
\hline & $(8.19)^{* *}$ & $(9.23)^{* *}$ & $(5.10) * *$ & $(5.12)^{* *}$ & $(7.61)^{* *}$ & $(7.26)^{* *}$ & $(6.54) * *$ & $(6.79)^{* *}$ & $(5.06) * *$ & $(5.66)^{* *}$ \\
\hline MES & -0.002 & 0.015 & 0.013 & 0.014 & -0.006 & 0.012 & 0.009 & 0.018 & 0.046 & 0.042 \\
\hline \multirow[t]{2}{*}{ Herfindahl } & -0.068 & -0.052 & -0.120 & -0.109 & -0.046 & -0.035 & -0.211 & -0.220 & -0.051 & 0.062 \\
\hline & $(0.37)$ & $(0.33)$ & $(0.73)$ & $(0.75)$ & $(0.40)$ & $(0.45)$ & (1.33) & (1.50) & $(0.33)$ & $(0.38)$ \\
\hline \multirow[t]{2}{*}{ Growth } & -0.202 & -0.203 & -0.138 & -0.236 & -0.072 & -0.048 & -0.172 & -0.211 & -0.130 & -0.268 \\
\hline & $(4.44)^{* *}$ & $(5.02)^{* *}$ & $(0.98)$ & $(2.89) * *$ & (1.78) & (1.42) & $(2.42)^{*}$ & $(3.43)^{* *}$ & $(0.96)$ & $(2.13)^{*}$ \\
\hline \multirow[t]{2}{*}{ Multinational share } & -0.118 & -0.188 & -0.077 & -0.046 & -0.148 & -0.256 & -0.102 & -0.140 & -0.172 & -0.199 \\
\hline & (1.03) & $(2.17)^{*}$ & $(0.26)$ & $(0.19)$ & (1.08) & $(2.48)^{*}$ & $(0.72)$ & (1.18) & (1.26) & (1.39) \\
\hline Observations & 4060 & 4060 & 4543 & 4543 & 4060 & 4060 & 4460 & 4460 & 4434 & 4434 \\
\hline
\end{tabular}

Robust z statistics in parentheses, * significant at 5\%; ** significant at 1\%. Standard errors are clustered at three-digit industry level. 
Figure 1: Importance of Multinationals in Manufacturing Industry

(Multinationals as percentage of total)

Plants

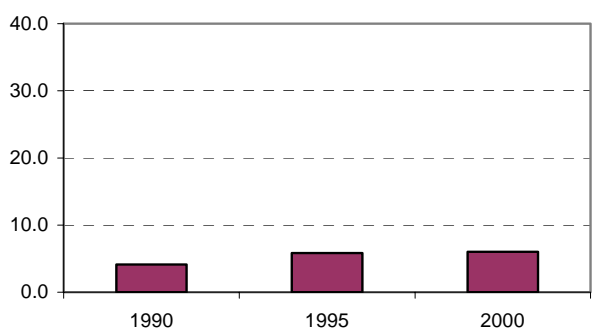

Value-Added

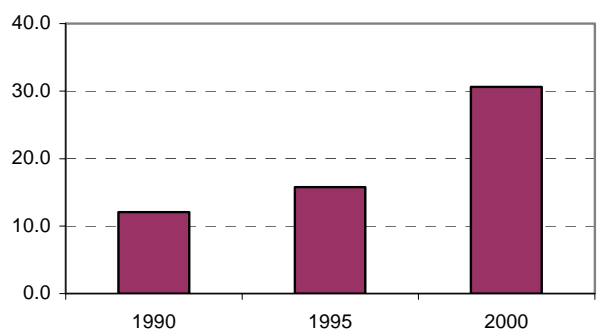

Employment

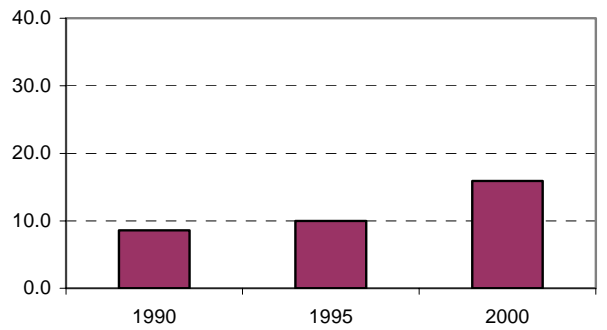

Exports

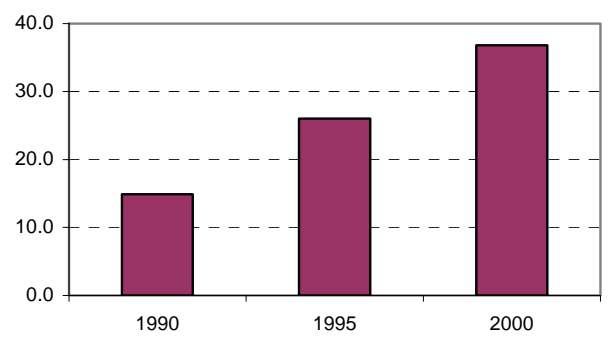

Source: Authors’ own calculations based on ENIA. 


\section{Appendix I}

Table A1: Results using different estimators

\begin{tabular}{l|ccc}
\hline & $\begin{array}{c}\text { Probit } \\
\text { Random } \\
\text { Effects }\end{array}$ & $\begin{array}{c}\text { Logit } \\
\text { Random } \\
\text { Effects }\end{array}$ & $\begin{array}{c}\text { Logit } \\
\text { Fixed } \\
\text { Effects }\end{array}$ \\
\hline \multirow{3}{*}{ Multinational } & & & \\
& -0.111 & -0.202 & -0.203 \\
AFP & $(0.85)$ & $(0.85)$ & $(0.86)$ \\
& -0.119 & -0.203 & -0.203 \\
Size & $(8.11)^{* *}$ & $(8.19)^{* *}$ & $(8.02)^{* *}$ \\
Exporter & -0.167 & -0.268 & -0.270 \\
& $(9.30)^{* *}$ & $(9.10)^{* *}$ & $(9.03)^{* *}$ \\
MES & -0.154 & -0.257 & -0.257 \\
Herfindahl & $(9.36)^{* *}$ & $(9.24)^{* *}$ & $(9.10)^{* *}$ \\
Multinational share & -0.034 & -0.057 & -0.057 \\
Growth & $(0.49)$ & $(0.46)$ & $(0.47)$ \\
1995-200 (D95-00) & 0.004 & -0.037 & -0.037 \\
Multinational*(D95-00) & $(0.02)$ & $(0.11)$ & $(0.11)$ \\
& -2.023 & -3.805 & -3.814 \\
Exporter*(D95-00) & $(1.34)$ & $(1.49)$ & $(1.52)$ \\
Observations & -0.103 & -0.330 & -0.334 \\
\hline & $(0.13)$ & $(0.24)$ & $(0.24)$ \\
& -0.442 & -0.736 & -0.738 \\
& $(2.76)^{* *}$ & $(2.67)^{* *}$ & $(2.67)^{* *}$ \\
& 0.522 & 0.862 & 0.859 \\
& $(7.16)^{* *}$ & $(6.95)^{* *}$ & $(6.95)^{* *}$ \\
& 0.321 & 0.551 & 0.551 \\
& $(2.11)^{*}$ & $(2.04)^{*}$ & $(2.07)^{*}$ \\
& 0.086 & 0.152 & 0.152 \\
& $(1.06)$ & $(1.08)$ & $(1.09)$ \\
& 8603 & 8603 & 8603 \\
\hline
\end{tabular}

Robust z statistics in parentheses, * significant at 5\%; ** significant at $1 \%$.

Standard errors are clustered at three-digit industry level. 